\title{
Digital Mind Mapping Learning Model to Increase Student Creativity
}

\author{
Fajar Bagja Gumilar Winata ${ }^{1, *}$, Rahmat Rahmat ${ }^{2}$ \\ ${ }^{1,2}$ Universitas Pendidikan Indonesia, Bandung, Indonesia \\ Corresponding author. Email: bagjafajar09@upi.edu
}

\begin{abstract}
This study aims to empirically test the effectiveness of civic education learning using digital mind mapping learning model to the creativity of learners. The sample of this study is students of class XI Science 1 Majalengka 1 Senior high school as an experimental class. This study uses quantitative approach with quasi method of pretest-posttest design experiment, data collection is conducted with research instruments in the form of pretest-posttest questions in experimental classes and control classes, measurement instruments of student creativity and questionnaires that refer to indicators of student creativity. Data analysis using Normalized Gain statistical test with statistical test hypothesis testing. The results showed an increase in the category of creativity of learners in the results of pretest-posttest in experimental classes that use digital mind mapping learning models, there was an increase in the low category of creativity of learners in the results of pretest-posttest tests in the control class using mind mapping models, there were differences in creativity skills seen from N-Gain in pretest-posttest test results in experimental classes and control classes, Digital mind mapping learning model is effective to increase the creativity of learners in civic education learning.
\end{abstract}

\section{Keywords: Civic Education Online Learning, Digital Learning, Digital Mind Mapping, Student Creativity.}

\section{INTRODUCTION}

Related to civic education as character education, the main component in realizing effective and efficient civic education learning focuses on the active role of learners when following the learning process. The current condition precisely during the covid-19 pandemic, certainly has a significant impact on Indonesian education, this causes Indonesian education needs to find a way out to deal with learning problems that cannot be implemented face-to-face. Related to this, educators are required to create and find solutions methods and media that support online learning, because innovations from efficiency of online learning in learning conditions in the era of the Covid-19 pandemic. The urgency of not rushing the research, the education process in Majalengka 1 senior high school will tend to be boring, innovation in terms of media and learning methods can overcome social distancing problems that limit learning to take place face-to-face.

The ability to implement, develop and convey new ideas and convey new ideas and thoughts with an open and responsive attitude to new things and views is the definition of Creativity. One's ability to create new mergers is another definition of creativity. The real conditions that occur in the field, namely in students of grade XI Science1 on Majalengka 1 senior high school in civic education learning it appears that the use of methods and media of face-to-face learning in online learning causes learners to be passive, the transition of face-to face learning into distance learning through online causes students to rely heavily on smartphones or other digital tools to follow learning should digital media be able to explore and even increase the creativity potential of learners this is characterized by (1). Lack of curiosity, (2). Passive learners in the question and answer process during the learning process, (3). Learners do not have their arguments and proposals but instead focus on textbooks, (4). Imagination is less characterized by a closed attitude in conveying ideas.

According to Wong Y. L. Creativity helps us solve problems in various fields.[1] Furthermore, according to Liesl M.B there is an attitude called Selfregulatory which is a supporting behavior in becoming a much better thinker and becoming more creative in work. [2] From various problems in students of class XI Sciencel certainly shows students who are not creative when associated with the characteristics of creativity according to Munandar among them are (1). Curiosity is high, (2). Ask positive questions, (3). Have their own arguments and proposals, (4). Have 
high imagination. [3] The results of Hidayati, N., Zubaidah, S., Suarsini, E., \&Praherdhiono, H. showed that there is a significant correlation between critical thinking and creativity when digital Mind Mapping is integrated into Learning. In addition, it was also found that both variables can be empowered simultaneously in the classroom in terms of improving creativity so it is highly recommended for future researchers in terms of the development of student creativity. [4] Mind Mapping according to Buzan is the process of mapping the mind to connect certain concepts that are poured into an interesting and creative writing. [5] Furthermore, according to Purdy, et al. who argue that learning patterns have shifted in the aspects of learning in the classroom as well as distance learning outside the classroom. [6] The difference between the models lies in the teaching style and motivation of learners and teachers, Digital learning is a breakthrough from the future that is considered quite effective in line with the development of technology that is increasingly becoming a demand. Then according to Sarah E. The workings of Mind Mapping in Education can also develop the learning process in a fun way, mind mapping can be used as a way or solution in obtaining information that can then be a creative tool for the brain in recording things containing ideas. [7]

Instructional practice and context, skills, attitude, beliefs, and values. The four elements are the main aspects that are in harmony with the three main elements of education, which include knowledge, affective and psychomotor, and in harmony with indicators of constitutional awareness, which includes knowledge, understanding, attitudes, and proper behavior. Digital mind mapping learning model is an innovation that aims to map the thinking of a problem digitally, problems associated with the material and then map it can be a medium to hone the creativity of learners. This emphasizes the flexibility of learners in finding the essence of the subject matter and looking for problems and things related to the material as material to be expressed into the form of digital Mind Mapping. Digital Mind Mapping in civic education learning is a solution in addressing the problem of civic education which is considered theoretical to be more practical. Digital Mind Mapping makes the process of recording more accommodating brain performance naturally and Mind Mapping is an innovation to provide convenience to students in remembering, storing and interesting and re-conveying the information obtained. The way Mind Mapping works in education can also develop the learning process in a fun, effective way of obtaining information that can then be sorted in the brain by mapping the mind. Therefore, teachers are now required to have the ability to provide examples related to and the practices in public life related to learning materials. [8]

The fact of the implementation of civic education learning in grade XI Science 1 on Majalengka I senior high school tends to focus on cognitive aspects and is considered less affective and psychomotor of learners. Thus, the competence of teachers is required in terms of developing creative learning strategies to foster affective and psychomotor aspects of course through appropriate media and learning models. Previous research on efforts to increase creativity, through the Model Mind Mapping conducted by Winata F. which conducted class actions related to the efforts of researchers in improving the creativity of learners to create the results of research students are considered less enthusiastic, this is because the methods and learning media using paper media and color markers are considered less following learning in the $21 \mathrm{st}$ century era. In the $21^{\text {st }}$ century, students have a dependence on the digital world accessed through smartphones to provide ease in learning and task work. Dependence on digital technology is the reason for the interest of researchers to apply the innovation of digital mind mapping learning model as a test in improving the creativity of learners in the Digital era of the $21^{\text {st }}$ century. The development of information and communication technology era has an impact on the dissemination and disclosure of information regardless of space and time. Life in today's digital age tends to connect people with the world of technology. Therefore technology has changed and influenced the lifestyle of people in public life so that if the ability to use technology less or "stutter technology" will hinder the mastery of information and cause lag in terms of getting a chance to advance.

Of the various problems faced by the test, this is because the model and learning media used tend to be passive. Considering that we reflect good citizens, we should use technology as wisely as possible both in learning and in daily activities. In this case the use of models and media in learning has an important position in civic education learning one of which is Digital mind mapping to increase the creativity of students of the $21^{\text {st }}$ century era that prioritizes elements of Digital technology in learning. Seeing such a problem creates obstacles to achieving the objectives of civic education if the learning process by educators continuously emphasizes the prevailing curriculum regardless of the current pandemic conditions because as a professional teacher a teacher is required to understand and have an ability to develop a model that is appropriate and effective, creative and fun. [10] The learning model in question is a learning model with digital media mind mapping, because this learning demands and stimulates students to create concepts and understanding of the subjects of Pancasila and Citizenship Education. Therefore, researchers are interested in researching about how the digital mind mapping learning model improves students' creativity in civic education learning. 


\section{THEORETICAL REVIEW}

\subsection{Civic Education}

The concept of civic education has nothing to do with the concept of citizenship science. When viewed from the difference that "the science of citizenship is theoretical, while Pancasila and Citizenship Education emphasizes more on practice.[11] Further based on NCSS that "civics education is process compresing all the positive influence which is intended to shape a citizen's view of his society".[12] Citizens are the object of study of civic education this is related to socio-cultural, economic and religious society. As Somantri opinion which is categorized in the object of study of civic education is human behavior, growth of thinking, potential, rights and obligations, ideals as well as aspirations, and conscious attitude of citizens to the value of pancasila and responsibility.[13] In this case civic education serves as a basic learning that is then designed in the focus of preparing citizens to play an active role in public life or the world of work in adulthood.[14] In general, civic education aims to form good citizens. According to Nurmalina \& Syaifullah the purpose of civic education is to "prepare critical, analytical, active, behave and democratic citizens".[15] The teaching strategy of civics and Civic Education Murray grouped into two strategies, namely teacher contered strategies and student contered strategies. Teacher contered strategies emphasize the dominant role of teachers in a teaching and learning process, while the position of learners remains in a passive state. Then student concered strategies focus more on the active role of learners in a learning process, while the role of teachers is directing and guiding.[11]

\subsection{Mind Mapping and Digital Mind Mapping}

Mind Mapping according to Buzan is the process of mapping the mind to connect certain concepts that are poured into an interesting and creative writing.[5] Sarah E. the workings of Mind Mapping in Education can also develop the learning process in a fun way, mind mapping can be used as a way or solution in obtaining information that can then be a creative means for the brain in recording things containing ideas.[7] Furthermore, according to Purdy, et al. who argue that learning patterns have shifted in the aspects of learning in the classroom as well as distance learning outside the classroom.[6] The difference between the models lies in the teaching style and motivation of learners and teachers, Digital learning is a breakthrough from the future that is considered quite effective in line with the development of technology that is increasingly becoming a demand. Digital mind mapping is the digitization of mind mapping method in general that aims to map a problem based on the main ideas and elements that are interrelated with using digital technology. Digital learning according to Munir opinion, digital Learning requires learners and teachers to communicate interactively by utilizing information and communication technology, such as computer media with the internet, mobile phones with various applications, video, telephone or fax. The utilization of this media depends on the structure of the learning materials and the types of communication required. This Digital learning in apply a web-based learning system or Digital. Digital learning begins with good planning, then the way learning materials are delivered (delivery content) to learners who should refer to the planning.[16] According to Helge, K. Using digital mind mapping technology encourages learners to convey their thoughts about new concepts or tasks unknown in digital format, and also inspires metacognitive thinking the process of thinking about or criticizing concepts or ideas about which ones are thought.[17] Budiarti, highlights the importance of creativity of learners in learning for the achievement of competencies where learners are able to create or develop an idea with creativity. [20] Furthermore, Setiawan in his research stated that in civic education learning the creativity of learners in learning becomes the key to the habit of learners using their creativity in various fields. [21] Abdullah said, a teacher in the learning process acts as an information presenter who understands the characteristics, abilities and differences in creativity between learners in following learning. [22] Mathews said, in learning related to facts, concepts, principles, and procedures as learning materials then realized through a process related to discovery, strengthening, interconnectedness and coherence. [23] Blanchard, contextual learning is a coordination of content with skills that concern intellectual learners. [24] Komalasari assumes a contestual learning approach capable of improving the competence of learners. [25] Suryosubroto stated that the use of discovery methods in learning is to provide opportunities for learners to search and find the information needed for themselves. [26] Ifania in his research mind mapping learning model in civic education learning makes it easier for learners to find and arrange concepts into a unity. [27] Mustofa in his research digital-based learning model, especially digital mind mapping in civic education learning is a learning innovation that was originally theoretical to be practical. [28] The ability of learners in remembering and expressing is very important because a knowledge is formed based on the interaction of these experiences. [29]

\subsection{Creativity}

Every human being is born with creative potential attached to the self that can then be identified and developed through an appropriate and accurate educational process. There is an attitude called Selfregulatory which is a supportive behavior in becoming a much better thinker person and becoming more creative in work.[2] Creativity in general according to Munandar opinion is the ability to produce or create something new.[3] Similarly, according to explains that creativity is the ability to make new combinations that have social significance.[3] It is quoted in 
stemberg and Lubart's opinion in the journal Yi Lin Wong "Creativity helps us solve problems in various fields. At the school level, students learn to be creative in their lessons in educational design."[1] Whereas according to Munandar suggests that creativity is the result of interaction between an individual and his environment, the ability to create new combinations, based on data, information, elements that have existed or been known before. characteristics of creativity according to Munandar among which are (1). Curiosity is high, (2). Ask positive questions, (3). Have their arguments and proposals, (4). Have high imagination.[3] Teachers should consider their role more as facilitators, and as counselors than as resource providers by allowing students to work on their own by encouraging students to access their own learning resources, asking students to reflect on their progress, giving participants to practice assignments, giving them the freedom to choose about topics, learning strategies, and learning materials. Baron concluded that creativity is an ability to create and produce something new.[30]

\section{METHOD}

This study uses quantitative approach with quasiexperimental method. in this study was incorporated into quasi-experiments because there is manipulation includes treatment of the learning process between the experimental and control groups. In addition, there is control of the learning process especially in digital mind mapping learning, then the last step is to observe the comparison of the learning results of two research classes. This research can be classified into quasi-experimental experimental experiments quasi experimental Design type The Nonequivalent Control Group Design or simply can be said to be pseudo experiments. Participants in the quasiexperimental study numbered 35 students of class XI Science 1 with details of 16 men, 19 women while the control group of 35 students of class XI Science 3, with details of 13 men and 22 women. Data collection techniques used are through observation, tests and questionnaires with data analysis techniques using SPSS Version 25.0 with validity, reliability, homogeneity, NGain calculation, hypothesis, paired wilcoxon and mann whitney test.

\section{FINDINGS AND DISCUSSION}

\begin{tabular}{|l|c|c|}
\hline & Eksperimen & Kontrol \\
\hline Spre & 15,17142857 & 10,42857143 \\
\hline Spost & 19,11428571 & 14,71428571 \\
\hline Gain & 0,401162791 & 0,294117647 \\
\hline Information & MEDIUM & LOW \\
\hline
\end{tabular}

Table 1. Test Results Gain pretest and posttest results experiment class and control class.
Creativity of experimental class learners in the initial test (pretest) and final test (posttest) increased with significance as in table 1 which is 0.40 which is categorized into a classification of moderate improvement. At first before the treatment of creativity score of learners is 15.17 then after treatment with digital mind mapping learning model creativity of learners increased to 19.11. The creativity of control class learners in the initial test (pretest) and final test (posttest) also increased with significance as in table 1 which is 0.29 which is categorized into a low increase classification. At first when pretest the student creativity score was 10.42 then after the posttest with the mind mapping learning model creativity of learners increased to 14.71 .

The increase in creativity of experimental class students in civic education learning is also supported by the results of the average different tests that have been conducted, in figure 1 Output shows that gis. Paired samples correlations $0.029<0.05$ and Asymp.sig. (2-tailed) $0.000<0.05$. If the value is Asymp.sig. (2-tailed) $<0.05$ then $\mathrm{H}_{1}$ is accepted then the $\mathrm{H}_{0}$ is to be obeyed.

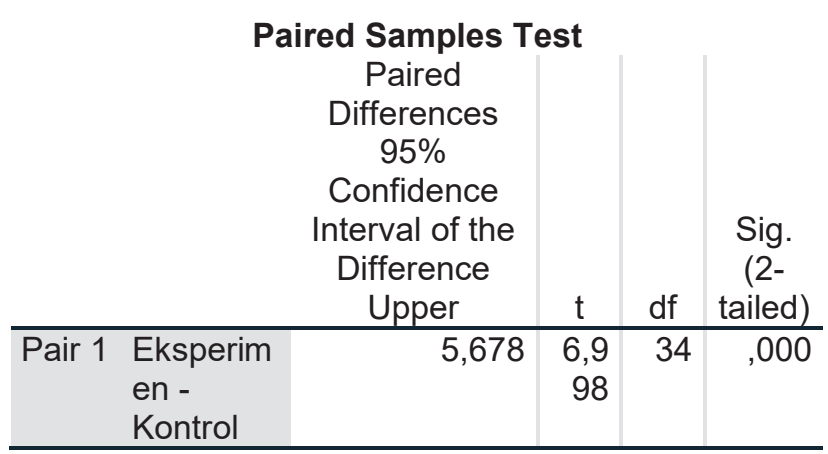

Figure 1. Hypothesis Test Results

\begin{tabular}{|c|c|}
\hline Normalized Gain Score & Interpretation \\
\hline $\mathrm{g}>0,7$ & High \\
\hline $0,3 \leq \mathrm{g} \leq 0,7$ & Medium \\
\hline $\mathrm{G}<0,3$ & Low \\
\hline
\end{tabular}

Table 2. Normalize and Interpretation Gain Score

Comparison of increased creativity of learners between experimental classes that use digital mind mapping learning models and control classes that use mind mapping learning models in the initial test (pretest) and final tests (posttest) in civic education learning, such as test results in table 1 of experiment class 17.14 and control class 12.56 , judging from the average results can be known the difference between the experimental class and the control class is 4.58 then it can be known the value of N-Gain experimental class is 0.40 which belongs to the category of increased creativity medium and control class 0.29 which belongs to the category of low creativity enhancement level according to figure 1 . 
The low creativity of control class learners in civic education learning is influenced by the learning model used, namely mind mapping which has limitations in distance learning used in research because the ideal civic education learning must be based on the right learning strategy, Djahiri argues that in civic education learning need to do habituation of good things starting from the classroom, school then home as a learning environment. According to Warseno opinion one of the shortcomings of mind mapping learning model is that during the learning process not all students follow the learning because of the lack of interaction between educators and students. In addition, the current condition precisely during the covid-19 pandemic, certainly has a significant impact on Indonesian education, precisely in Majalengka 1 senior high school this causes education needs to find a way out to deal with learning problems that cannot be implemented face-to-face. Digital Mind Mapping Learning Model To Increase Student Creativity can be seen from the average score of pretest and posttest results that showed the value of $\mathrm{N}$-Gain experimental class is 0.40 which belongs to the category of moderate creativity improvement and control class 0.29 which belongs to the category of low creativity improvement rate according to figure 1 .

In addition, the effectiveness of digital mind mapping learning model can also be seen from the score of digital mind mapping results to measure the level of creativity of learners. The basis of scoring decision making on treatment is based on the scoring instrument with a total of 25 in category 5 well, 3 enough and 1 less in each question and 19-25 good, 9-18 enough and 1-8 less in the total score. The output shows that 26 students can be categorized into a good level of creativity, 9 students enough and 0 for students who are categorized into less creativity levels.

A professional teacher is required to understand and have an ability to develop a model that is appropriate and effective, creative and fun. [10] Digital mind mapping learning is an effective model to increase the creativity of learners in civic education learning is also felt directly by students based on the results of questionnaires filled by the entire student or $100 \%$ of respondents as well as questionnaire analysis conducted by researchers. The output shows that the criterium score shows an SB (excellent) scale in the range of answer values of $106-140$ questionnaire scores per question. Thus, it can be concluded that there is an influence on the experimental class after getting treatment by applying a digital learning model mind mapping on civic education learning to increase the creativity of learners.

\section{CONCLUSION}

From the results of the $\mathrm{H}_{1}$ test received and $\mathrm{H}_{0}$ rejected means the influence on the experimental class after getting treatment by applying digital Mind Mapping learning model on civic education learning. There is a greater influence of increased creativity on the experimental class after getting treatment by applying digital Mind Mapping learning model on civic education learning compared to control classes that use mind mapping learning model. It can also be seen from the score of digital mind mapping results to measure the level of creativity of students output shows that 26 students can be categorized into a good level of creativity, 9 students enough and 0 for students who are categorized into less creativity levels. Then reinforced by the results of the stuffing and analysis of the questionnaire of learners filled by the entire student or $100 \%$ of respondents, Output showed that the criterium score showed the SB scale (very good) in the range of answer scores of 106 - 140 questionnaire scores per question. This is because the mind mapping learning model is less effective in improving the creativity of learners in civic education learning, so it can be concluded that the digital mind mapping learning model is effective to increase the creativity of student in civic education learning.

\section{REFERENCES}

[1] Y. L. Wong, "A model of creative design process for fostering creativity of students in design education", 22:437-450. 2012

[2] L. M. Baum and P. L. Newbill, "A Journey Through a Jamestown-Era Native American Village. Instructional Design as Critical and Creative Thinking", 54:5:27-37. 2010.

[3] U. Munandar, "Pengembangan Kreativitas Anak Berbakat" Jakarta: Rineka Cipta. 2009.

[4] N. Hidayati, S. Zubaidah, E. Suarsini, \& H. Praherdhiono, "Examining the relationship between creativity and critical thinking through integrated problem-based 1 learning and digital mind maps" Universal Journal of Education Research, 7(9A), 171179. 2019.

[5] T. Buzan, "Buku Pintar Mind Map". Jakarta: PT. Gramedia Pustaka Utama. 2009.

[6] Purdy, James, and W. Cabot Wright, "Cabot Wright Begins”. New York: LIverlight.1992.

[7] S. Edwards, \& N. Cooper, "Mind mapping as a teaching resource". The clinical teacher, 7(4), 236239. 2010.

[8] Badan Standar Nasional Pendidikan, "Standar Isi". Badan Standar Nasional Pendidikan: Jakarta. 2010.

[9] Fajar Bagja Gumilar Winata, "Upaya Meningkatkan Kreativitas Peserta Didik dalam Pembelajaran PPkn Melalui Metode Mind Mapping”. FPIPS-Universitas Pendidikan. 2019.

[10] K. Komalasari, "Pembelajaran Kontekstual konsep dan aplikasi”. Bandung: PT. Refika Adiatama. 2011.

[11] Wuryan, Sri dan Syaifullah. "Ilmu Kewarganegaraan 
(Civics)". Bandung: Penerbit Labolatorium Pendidikan Pancasila dan Kewarganegaraan.2008.

[12] Suriakusumah, dkk. "PKn dan Kemasyarakatan". Jakarta: Universitas Terbuka.1999.

[13] Somantri, Muhammad Numan. "Metode Mengajar Civics". Jakarta: Erlangga.1976.

[14] P. D. Surya, "Implementasi Proses Pembelajaran Pendidikan Pancasila dan Kewarganegaraan Bagi Pengembangan Semangat Bela Negara Mahasiswa". Jurnal Pendidikan Pancasila dan Kewarganegaraan, $1: 1$ - 66. 2018.

[15] Nurmalina, Komala dan Syaifullah. "Memahami Pendidikan Pancasila dan Kewarganegaraan". Bandung: Laboratorium PKn. 2008.

[16] Munir, "Pembelajaran Digital". Bandung: Alfabeta Cetakan: Desember 2017 ISBN: 978-602-289-347-9. 2017.

[17] K. Helge, \& L. McKinnon, "The teaching librarian". Web 2.0, technology, and legal aspects. Elsevier. 2013.

[18] Djahiri, A. Kosasih, "Esensi pendidikan moral-nilai dan PKn di era globalisasi" dalam pendidikan nilai dan moral dalam dimensi Pendidikan Pancasila dan Kewarganegaraan. Bandung: Laboratorium Pendidikan Pancasila dan Kewarganegaraan FPIPSUniversitas Pendidikan Indonesia. 2006.

[19] A. Warseno, "Super Learning". Jogjakarta: Diva Pers. 2011.

[20] Y. Budiarti "Pengembangan kemampuan kreativitas dalam pembelajaran IPS" UM Metro, 3(1), 61-72. 2015.

[21] D. Setiawan, "Pendidikan Kewarganegaraan Berbasis Karakter melalui Penerapan Pendekatan Pembelajaran Aktif, Kreatif, Efektif dan Menyenangkan.” Jurnal Pendidikan Ilmu-Ilmu Sosial, 6(2), 61-72. 2014.

[22] R. Abdullah, "Pembelajaran dalam perspektif kreativitas guru dalam pemanfaatan media pembelajaran.” Lantanida Journal, 4(1), 35-49. 2017.

[23] B. Mathews, "Integrated Curriculum in Use: Practical Ideas for Planning and Assessment." Melbourne: Ashton Scholastic Pty Limited. 1993.

[24] A. Blanchard "Contextual Learning" Jurnal Pendidikan Ilmu-Ilmu Sosial. 2001.

[25] K. Komalasari, "Pembelajaran Kontekstual konsep dan aplikasi”. Jurnal Pendidikan Ilmu-Ilmu Sosial. 2010.

[26] B. Suryosubroto, "Proses belajar mengajar di sekolah” Jakarta: PT. Rineka Cipta. 2009.

[27] Ifania, "Meningkatkan kreativitas peserta didik dengan digital mind mapping" Jurnal Pendidikan Ilmu-Ilmu Sosial. 2011.

[28] A. Mustofa, "Pembelajaran PPKn berbasis digital mind mapping" Jurnal Pendidikan Ilmu-Ilmu Sosial. 2019.

[29] K. Komalasari, "Pembelajaran konstruktivisme".
Jurnal Pendidikan Ilmu-Ilmu Sosial. 2012.

[30] Baron, "kreativitas peserta didik dalam pembelajaran" Jurnal Pendidikan Ilmu-Ilmu Sosial. 2009. 